\title{
Scholars and Literati at the Royal Prussian Academy of Sciences (1700-1800)
}

\author{
David de la Croix \\ IRES/LIDAM, UCLouvain
}

\author{
Thomas Eisfeld \\ CORE/LIDAM, UCLouvain \\ ECARES, ULB
}

\author{
Maximilian Ganterer \\ IRES/LIDAM, UCLouvain
}

This note is a summary description of the set of scholars and literati who participated in the activities of the Royal Prussian Academy of Sciences in Berlin, from its inception in 1700 to the eve of the Industrial Revolution (1800).

\section{The ACADEMY}

The Royal Prussian Academy of Sciences, though sponsored by the aristocratic family Hohenzollern, was intellectually founded by Gottfried Wilhelm von Leibniz. During a stay in Paris, Leibniz was inspired by the French Academy of Sciences, and was an enthusiastic advocate for the establishment of a similar academy in the Holy Roman Empire. The first King of Prussia, Friedrich I, was eventually persuaded to generate funding for the institution by granting it a monopoly on calendar production. In the spirit of its versatile founder, the Academy promoted research in the humanities as well as the natural sciences. Under the leadership of the Prussian King, and connoisseur of science, Friedrich II, the Academy came to be recognized as a scientific heavyweight by the middle of the 18th century.

\section{SOURCES}

The Royal Prussian Academy of Sciences eventually became the Berlin-Brandenburg Academy of Sciences and Humanities, and the website of this younger institution has a list of the early members of the Royal Prussian Academy. The list includes a brief biography of each member and is a source for the descriptions of the most prolific scholars between 1700-1800. The material on the website is based on Amburger (1950) and Hartkopf (1992). The description of the early days of the Academy and some anecdotal pieces are drawn from Harnack (1900).

\section{SOME STATISTICS}

Table 1 shows some descriptive statistics. There are 721 scholars and literati. The year of birth is known for $97.5 \%$ of them. The mean age at appointment is 43.7 years, and this is quite stable over the two periods (1686-1733 and 1734-1800). Our two measures of longevity, the mean age at death and the expected age at death when 30 , show a marked increased over time. The birth place is known for $96 \%$ of the people. The median distance between birth and Berlin is $451 \mathrm{~km}$, a high number. $74.3 \%$ of the scholars have a Wikipedia page (in some language), which is a large percentage. This Academy had very few obscure scholars. Even more impressive, 94\% of them have left a footprint in the catalogues of the libraries of the world, Worldcat, either by having published some work, or by having been the subject of published books and articles.

\section{FIELDS}

Figure 1 shows the relative importance of fields, broadly defined. The distribution of fields highlights that the Royal Prussian Academy of Sciences had a more interdisciplinary approach than other 


\begin{tabular}{|c|c|c|c|c|c|c|}
\hline \multicolumn{2}{|c|}{ Period } & nb. & $\%$ birth year & mean age & mean age & exp. age \\
\hline Start & End & obs & known & at appoint. & at death & at death \\
\hline 1686 & 1733 & 306 & 96.1 & 42.7 & 63.6 & 58.2 \\
\hline 1734 & 1800 & 415 & 98.6 & 44.4 & 67.2 & 63.6 \\
\hline 1000 & 1800 & $\overline{72} \overline{1}$ & $\overline{9} \overline{7} . \overline{5}$ & 43.7 & $\overline{6} \overline{5} . \overline{7}$ & 61.3 \\
\hline & & & $\begin{array}{l}\text { \% birth place } \\
\text { known }\end{array}$ & $\begin{array}{l}\text { median distance } \\
\text { birth-institution }\end{array}$ & $\begin{array}{c}\% \text { with } \\
\text { Wikipedia }\end{array}$ & $\begin{array}{c}\% \text { with } \\
\text { Worldcat }\end{array}$ \\
\hline 1686 & 1733 & & 94.8 & 362 & 62.4 & 92.2 \\
\hline 1734 & 1800 & & 96.9 & 600 & 83.1 & 95.4 \\
\hline 1000 & 1800 & & $9 \overline{6} .0$ & $45 \overline{1}$ & $\overline{7} \overline{4} . \overline{3}$ & 94.0 \\
\hline
\end{tabular}

Table 1: Summary statistics by period

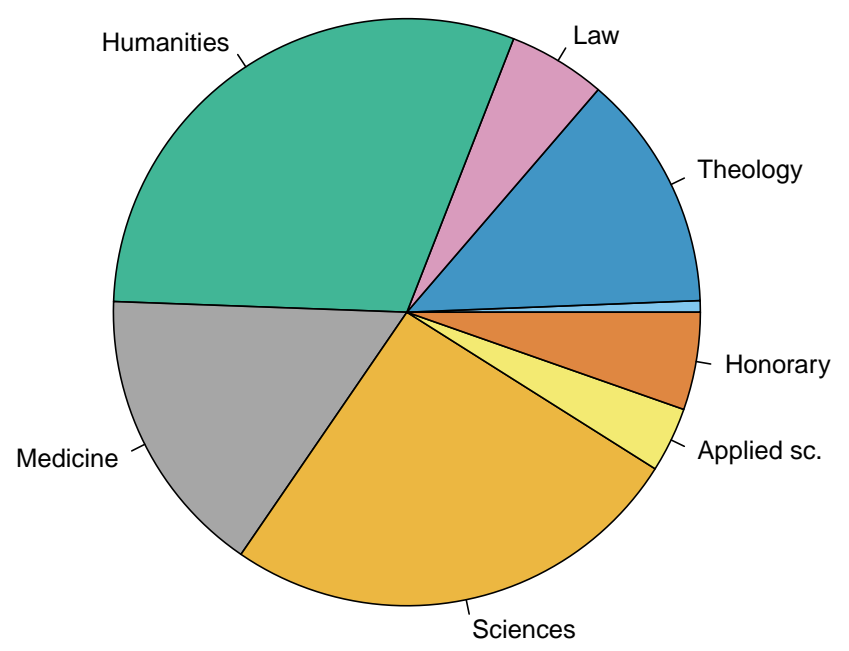

Figure 1: Broad fields at Berlin

contemporary scientific academies at that time in Europe (see for instance De la Croix (2020) and De la Croix and Ganterer (2020)). In particular, humanities and sciences are represented by an equal share of scholars, and medicine and theology are also almost in balance. A few scholars in law and the applied sciences complete the range of fields represented. The academy also includes some persons we classified as honorary, who were essentially there to provide political support to its activities.

\section{Place of Birth}

Figure 2 is a plot of the places of birth of all the ordinary members of the Royal Prussian Academy of Sciences. The places of birth show both the Prussian character of the Academy and the French influence. Because of the migration of Huguenots to Berlin, French was already widely spoken, and was the working language even under Friedrich II. This made it even easier to attract more French scholars.

Figure 3 is a plot of the places of birth of all the scholars of the Royal Prussian Academy of Sciences who were external members. The plot shows that the Academy attracted literati from all over Europe, especially under the protection of Friedrich II (he became Protector of the Academy in 1740). 


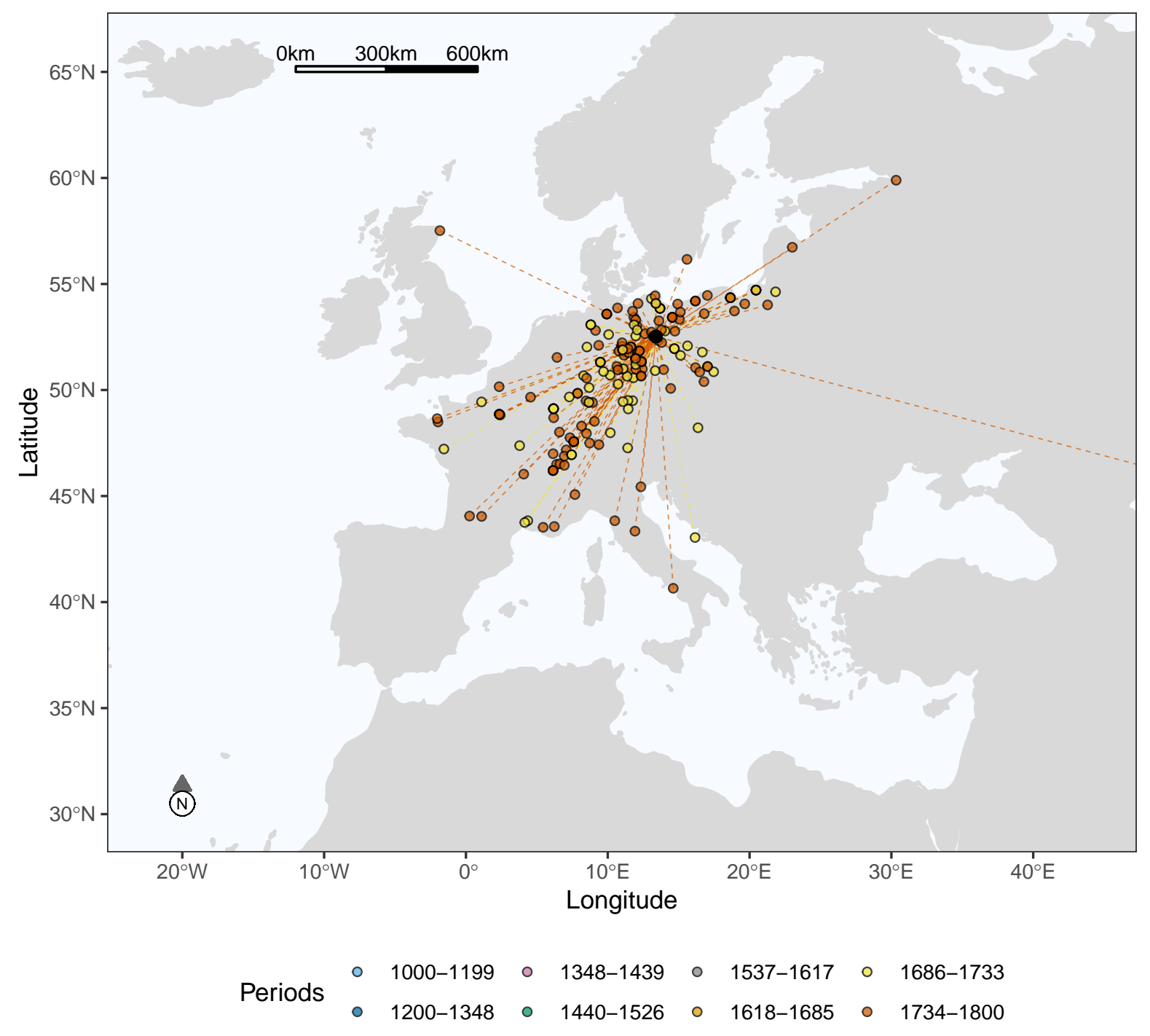

Figure 2: Place of birth of the scholars and literati at the Royal Prussian Academy of Sciences Ordinary members 


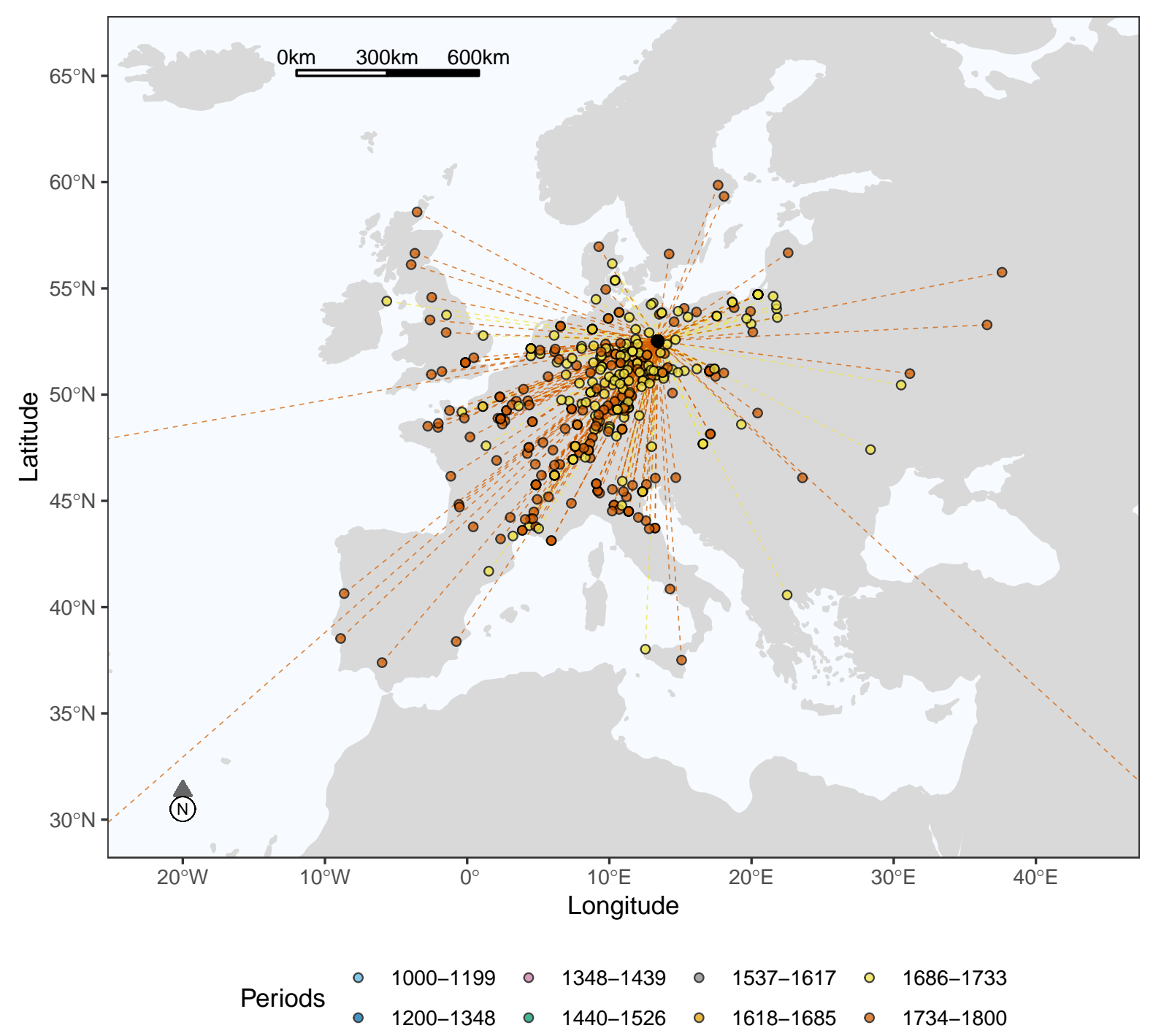

Figure 3: Place of birth of the scholars and literati at the Royal Prussian Academy of Sciences External members

\section{HUMAN CAPITAL OF SCHOLARS AND LITERATI}

For each person in the database we compute a heuristic human capital index, identified by combining information from Worldcat and Wikipedia using a principal component analysis. Details are given in the Appendix. Figure 4 shows the names of all the scholars with a positive human capital index. The vertical green lines (rug plot) show the distribution of all scholars, including the obscure ones, over time.

\section{TOP 5 MEMBERS}

We now provide a brief overview of the five ordinary members with the highest human capital index.

Gottfried Wilhelm von Leibniz (Leipzig 1646 - Hannover 1716) was a German polymath. Regarded as one of the most influential philosophers of the Enlightenment, he was appointed first president of the Royal Prussian Academy of Sciences in 1700. He is mostly known for his contributions to mathematics, including differential and integral calculus and the binary numeral system. Leibniz was one of the greatest advocates of rationalism in the 17th century and his works laid the cornerstone for later developments in philosophy, probability theory, biology, medicine, geology, psychology, linguistics, and computer science. 


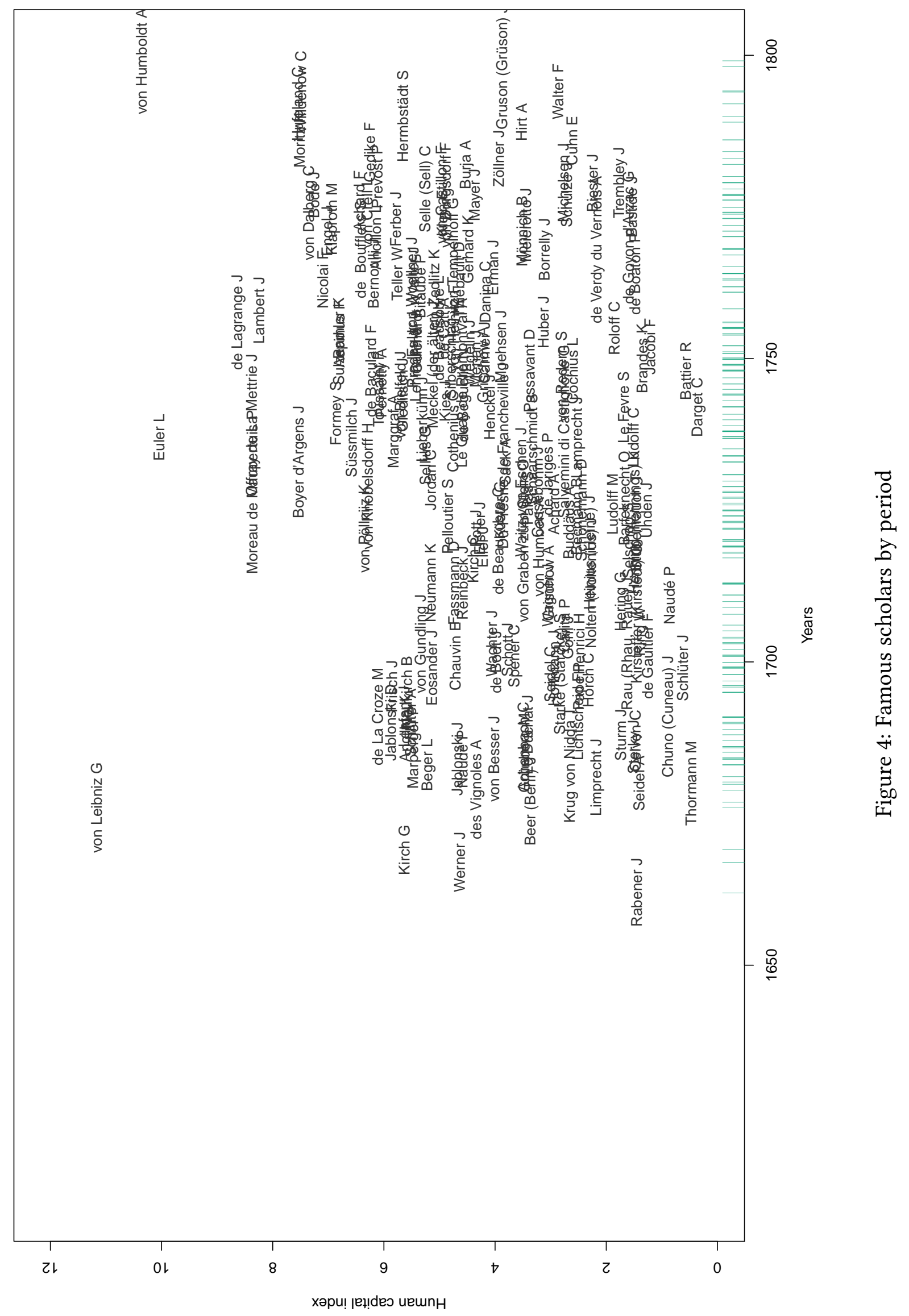


Alexander von Humboldt (Berlin 1769 - Berlin 1859) was a scientist and explorer. His pioneering work on botanical geography paved the way for new disciplines, such as biogeography and modern geomagnetic and meteorological monitoring. Alexander von Humboldt entered the academy as an extraordinary member in 1800 , and became an ordinary member in 1805 . He soon gained membership of numerous other learned societies. He is believed to be the first person to describe human-induced climate change. The Humboldt Current is named after him.

Leonhard Euler (Basel 1707 - Saint Petersburg 1783) was a mathematician, physicist, astronomer and logician. In 1741 he obtained membership of the Royal Prussian Academy of Sciences and became the head of the Academy's observatory; he was appointed director of the mathematics section in 1746. Although he was never formally appointed to the position of Academy president, he later managed and supervised administrative activities within the Society until he departed for Saint Petersburg. Euler is mostly known for his groundbreaking works in probability theory, calculus, graph theory, mechanics and music theory.

Julien Jean Offray de La Mettrie (Saint-Malo 1709 - Berlin 1751) was a physician and, as a philosopher, one of the earliest French materialists of the Enlightenment. After serving as a surgeon in the French military, he was forced to quit his occupation in 1745 after three years of service, when his hedonistic and materialistic views sparked an outcry in French society. He was elected as a member of the Royal Prussian Academy of Sciences in 1748. La Mettrie is best known for his philosophical works Histoire Naturelle de l'Âme and L'homme machine, describing human beings as complex animals.

Joseph-Louis de Lagrange (Torino 1736 - Paris 1813) was an Italian astronomer and mathematician, known for his substantial contributions to analysis, number theory, and mechanics. Euler recommended Lagrange as his successor, and Lagrange became director of the mathematics section in 1766. He stayed in Berlin for about 20 years before returning to France. Lagrange was instrumental to the introduction of the metric system and served as a French senator in 1799.

\section{RELATED SCHOLARS}

We provide here a brief overview of the five external members with the highest human capital index.

François-Marie Arouet de Voltaire (Paris 1694 - Paris 1778) was a French philosopher, historian and writer. Unlike most other Enlightenment philosophers, Voltaire presented his philosophical critics in a variety of forms, such as poems, plays, novels, essays, and scientific expositions. Writing more than 2000 pieces over his lifetime, he quickly became an internationally renowned and commercially successful author. As a strong advocate of free speech and famous for his criticism of Christianity, Voltaire became an external member of the Academy in 1746. His argument in favour of secular and sovereign governments has significantly influenced the development of political systems around the world.

Immanuel Kant (Kaliningrad (Königsberg) 1724 - Kaliningrad (Königsberg) 1804) was a philosopher and a central figure of the of Enlightenment. After becoming affiliated to the University of Königsberg in 1755, he joined the Academy in 1786. He was also elected rector of the University of Königsberg in the same year. Kant's works on ethics and morality paved the way for modern philosophy and significantly shaped present-day Western philosophy. During his lifetime, Kant also contributed to other disciplines such as mathematics, astronomy and geography.

Denis Diderot (Langres 1713 - Paris 1784) was a materialistic philosopher and central to the French Enlightenment. He was the editor-in-chief, with d'Alembert, of the Encyclopédie, 28 volumes aimed at gathering and disseminating all of the world's knowledge (see the anecdote in the next issue of RETE on the Spanish Academy). He joined the Royal Prussian Academy of Sci- 
ences in 1751 as an external member. Much of his work in philosophy was dedicated to questions about personal autonomy and the mind-body problem. Diderot also wrote important pieces of literature, including plays, and made a large contribution to art theory. He served Empress Catherine the Great of Russia as an artistic advisor.

Gotthold Ephraim Lessing (Kamenz 1729 - Braunschweig 1781) was a German poet, writer and philosopher, whose works influenced the development of German literature. His plays laid the foundation for new styles of drama, freed from the classical French models, and are considered to be pieces of lasting importance. Lessing was the first dramaturge of the Hamburg National Theatre. He was invited to become an external member of the Royal Prussian Academy of Sciences in 1760 .

Charles-Louis de Secondat Baron de la Brède et de Montesquieu (La Brède (Bordeaux) 1689 - Paris 1755) was a French philosopher and statesman, as well as a legal and social historian. His fictitious work, Lettres persanes, played a central role in the French Enlightenment. Elected as an external member of the Royal Prussian Academy of Sciences in 1746, Montesquieu was also made a member of the Académie Française and the Royal Society in 1727 and 1730, respectively. His theory of separation of powers, advocating the division of administrative power into executive, legislative and judicial branches, has shaped many governments around the world.

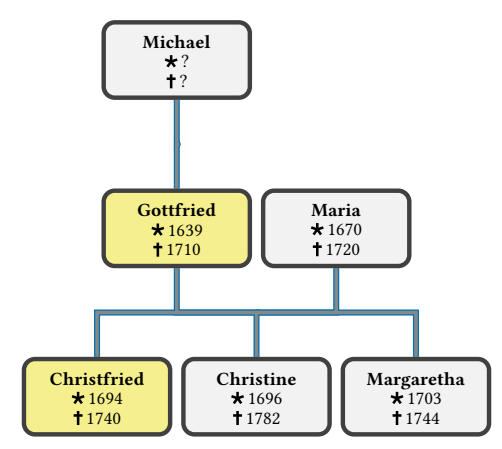

Figure 5: The Kirch family. Members of the Prussian Academy in yellow squares

\section{FAMILIES OF SCHOLARS}

We counted 22 father-son pairs among the members of the Prussian Academy. There are some very famous families, including the Bernoullis and the Eulers, but we have chosen to show a small German family instead. The father, Michael Kirch, was a shoemaker in Guben. His son Gottfried was an astronomer and calendar maker, who become one of the first members of the Academy in 1700. Gottfried's wife Maria was also astronomer (see Ogilvie (1986)). Their son Chrisfried became a member of the Academy in 1717. Following the death of Christfried, the Academy relied on his two sisters, Christine and Margaretha, to continue the profitable production of calendars and almanacs.

\section{INTERSECTION WITH LEOPOLDINA}

Figure 6 shows the intersection between the two main Germanic academies of the eighteenth century, the Royal Prussian Academy and the Leopoldina. The latter is centered on natural sciences and medicine, hence its name Academia Naturae Curiosorum. There are 112 scholars who were members of both academies, but a large majority of scholars were associated with only one of the two institutions. This provides some insight into the extent to which Leopoldina and the Royal Prussian Academy were complements or substitutes during that period. 


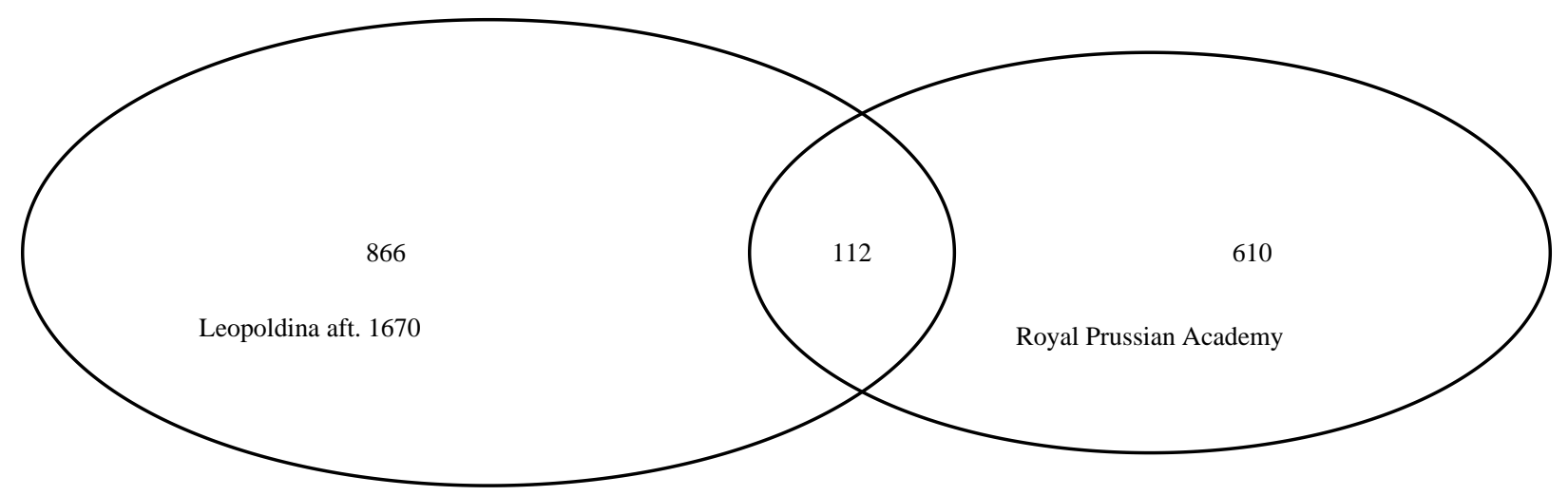

Figure 6: Intersections of the lists of scholars of the Royal Prussian Academy and Leopoldina

\section{ANECDOTES}

The Academy was not well received by the local community. Bookmakers resented its monopoly on the production of calendars, and there was a perception that some members of the Academy - most notably Christian Oelven (born in 1657) - were more motivated by money than scientific endeavour. This alarmed the more scholarly members, who feared for the reputation of the Academy. Mathurin Veyssière de La Croze (1661 - 1739) in particular engaged in quarrels with Oelven and his comrades. Feeling insulted La Croze wrote venomous letters to Leibniz in which he announced his intention to leave the Academy, because he did not want to be part of an Academy whose members ought to be in a mental home - a "societas obscurorum virorum". This incident reflects the difficult beginnings of the Prussian Academy.

At the request of Friedrich II, in 1741, Leonhard Euler (1707 - 1783) moved from Saint Petersburg to Berlin. The mother of Friedrich II enjoyed chatting with him. However, Euler was a quiet man, and explained his silence with the following apology: "Majesty, I am coming from a country (Russia) in which people get hanged, if they are talking."

\section{APPENDIX}

The individual human capital index $q_{i}$ of an individual $i$ is given by:

$$
\begin{aligned}
q_{i}= & -1.76+0.43 \ln (\mathrm{nb} . \text { characters of the longest Wikipedia page }) \\
& +0.40 \ln (\mathrm{nb} . \text { wikipedia pages in different languages })+0.47 \ln (\mathrm{nb} . \text { works in Worldcat }) \\
& +0.46 \ln (\text { nb. publication languages in Worldcat })+0.47 \ln (\mathrm{nb} \text {. library holdings in Worldcat })
\end{aligned}
$$

We assume that having no Wikipedia page is similar to having one page with a length of 60 characters and that having no Worldcat page is similar to having a page with one work in one language held by one library. The constant -1.76 normalizes $q_{i}$ at 0 when there is neither a Wikipedia page, nor a Worldcat page. The weights $(0.43,0.40$, etc $)$ are obtained from the first principal component of the five indicators (De la Croix et al. 2020).

\section{ACKNOWLEDGMENTS}

This project has received funding from the European Research Council (ERC) under the European Union's Horizon 2020 research and innovation programme under grant agreement No 883033 "Did elite human capital trigger the rise of the West? Insights from a new database of European scholars."

First version February 15, 2021. Updated September 5, 2021. 


\section{REFERENCES}

Amburger, Erik. 1950. Die Mitglieder der Deutschen Akademie der Wissenschaften zu Berlin 1700-1950. Berlin: Akademie-Verlag.

De la Croix, David. 2020. "Scholars at the Royal Society of Sciences of Montpellier (1706-1793)." Repertorium eruditorum totius Europae 1:33-39.

De la Croix, David, Frédéric Docquier, Alice Fabre, and Robert Stelter. 2020. "The Academic Market and the Rise of Universities in Medieval and Early Modern Europe (1000-1800)." CEPR Discussion Paper 14509.

De la Croix, David, and Maximilian Ganterer. 2020. "Scholars and Literati at the Danzig Research Society (1743-1800).” Repertorium eruditorum totius Europae 1:49-54.

Harnack, Adolf. 1900. Geschichte der Königlich Preussischen Akademie der Wissenschaften zu Berlin. Berlin: Reichsdruckerei.

Hartkopf, Werner. 1992. Die Berliner Akademie der Wissenschaften. Akademie-Verlag.

Ogilvie, Marilyn Bailey. 1986. Women in science: antiquity through the nineteenth century: a biographical dictionary with annotated bibliography. Cambridge MA: MIT Press. 